http://kitaibelia.unideb.hu/

ISSN 2064-4507 (Online) • ISSN 1219-9672 (Print)

(C) 2015, Department of Botany, University of Debrecen, Hungary

20 (2): 193-201.; 2015

DOI: $10.17542 /$ kit.20.193

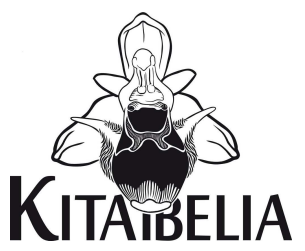

\title{
Bruchia flexuosa (Schwägr.) Müll. Hal.: egy igazi különlegesség a magyar mohaflórában
}

\author{
NÉMETH Csaba ${ }^{1} \&$ MESTERHÁZY Attila²
}

(1) BCE KeTK Növénytani Tanszék és Soroksári Botanikus Kert; nemetcsaba@gmail.com (2) H-9500 Celldömölk, Hunyadi utca 55.

\section{Bruchia flexuosa (Schwägr.) Müll. Hal. a true peculiarity in the Hungarian bryoflora}

\begin{abstract}
The fifth European occurrence of the moss species Bruchia flexuosa possessing a holarctic distribution range with a North American centre was encountered in Hungary. Outside of the North American continent only two Asian (both from Japan) and four European occurrences from four different countries (Italy, Austria, Slovenia, Croatia) have hitherto been reported. Apart from the recent Japan findings and the Croatian record observed in 1987, all other European records date back to the $19^{\text {th }}$ century. Our paper reports the circumstances of the Hungarian occurrence along with a short descriptions and photographic illustrations of both the species and its habitat.
\end{abstract}

Keywords: Bruchiaceae, bryoflora of Hungary, Europe, rare mosses

Összefoglalás - A Bruchia flexuosa egy holarktikus faj észak-amerikai elterjedési centrummal. Az amerikai kontinensen kívül ez idáig csak Japánból jelezték kettő, valamint Európából négy előfordulását (Olaszország, Ausztria, Szlovénia, Horvátország). A recens japán előfordulások mellett az európai adatok - az 1987-ben talált horvátot leszámítva - mind a 19. századból származnak. Az újonnan felfedezett Barcs környéki populáció a faj ötödik észlelése Európában és a hetedik az északamerikai térségen kívül.

Kulcsszavak: Bruchiaceae, Európa, florisztika, Magyarország mohaflórája, ritka mohák

\section{Bevezetés}

Hazánk mohaflórája az utóbbi évtizedekben egyre intenzívebbé váló terepi kutatásoknak [például Campylopus flexuosus (Hedw.) Brid. (ERzBerGer \& NÉmETH 2014)], herbáriumi revízióknak [például Gymnostomum viridulum Brid. (PAPP 2009a)], új fajleírásoknak [például Conocephalum salebrosum Szweykowski, Buczkowska et Odrzykoski (PAPP 2009b)], illetve a komplikáltabb csoportok jobb megismerésének köszönhetően [például Schistidium lancifolium (Kindb.) H. H. Blom (ERZBERGER \& SCHRÖDER 2008)] újabb és újabb fajokkal bővül. Nagy részük Európa más területein - beleértve a szomszédos országokat is - kisebb-nagyobb gyakorisággal, őshonosan jelen van és hazai előfordulásuk tulajdonképpen nem meglepő.

A hazai flórára újonnan felfedezett mohák másik csoportját a neofiton, expanzióval jellemezhető fajok alkotják. Ezek egy része már stabilan meghonosodott hazánkban, mint a déli féltekéről származó Campylopus introflexus (Hedw.) Brid. (SzŰ́CS \& ERZBERGER 2007, SzŰCS 2007, 2009, 2012, SzÚCS et al. 2014), mely az 1941-es angliai behurcolása (RICHARDS 1963) óta napjainkra Európa-szerte elterjedt, helyenként inváziós jellegű fajjá vált (HASSEL \& SÖDERSTRÖM 2005, VELLAK et al. 2009, YAYINTAŞ 2009, MiKULÁŠKOVÁ et al. 2012). Más részük, 
mint például az Európából először 1910-ben előkerült (BURRELL 1940) és szintén a déli félteke mérsékelt övi területeiről származó Orthodontium lineare Schwägr. csak egy lelőhelyről ismert hazánkban és ez idáig intenzív terjedésére utaló jelek sem mutatkoznak (SzÚCS \& BidLó 2012). A Leptophascum leptophyllum (Müll. Hal.) J. Guerra \& M.J. Cano (Phascum leptopyllum Müll. Hal.), eredetileg egy tropikus-szubtropikus areájú faj, szintén neofitonként van jelen Európa néhány országában (FRAHM 2012), beleértve Magyarországot is (ZANTEN 2000). A külföldi tendenciák alapján további hazai terjedésére lehet majd számítani (PAPP et al. 2010).

Európa adekvát klímahatás alatt álló részein stabilan jelen lévő, a hazai mohaflórát viszont feltehetően csak átmenetileg gazdagító, alkalmi megjelenésű fajok például az Amblyodon dealbatus (Hedw.) P. Beauv. [európai boreális-montán flóraelem (SмITH 2004)], valamint a Plagiothecium undulatum (Hedw.) Schimp. [északi-mérsékelt szubóceánikus flóraelem (SMITH 2004)]. Előbbi, a hazai vörös listákon RE (regionálisan kipusztult) besorolással szereplő faj (RAJCZY 1990, PAPP et al. 2010), egyetlen hazai előfordulása a Vértes északi előteréből ismert egy meszes forrás környezetéből (BoROs 1915-1971, BoRos 1968), ahonnan a későbbi, többszöri, célzott keresések ellenére sem került elő újra, és új előfordulásai sem váltak ismertté. A Plagiothecium undulatum egy a globális elterjedését tekintve rendkívül érdekes, az óceáni klímahatástól nagymértékben függő, diszjunkt areájú faj. Globális előfordulása két nagy területre korlátozódik, Észak-Amerika nyugati partvidékére, valamint Európa atlantikus klímahatás alatt álló régióira (FRAHM 2012). Magyarországról mindössze 3 alkalommal került elő, kicsiny, instabil populációkkal (BoROS 1968, JAKAB 1997, NÉMETH 2008).

Európai léptékben külön csoportot alkotnak azok a fajok, amelyek vagy a trópusi régiókban vagy Észak-Amerika mérsékelt klímájú területein élnek. Ezen fajok rendkívül sporadikus és sokszor csak alkalomszerû európai megjelenése egyes elméletek szerint vulkánkitörésekhez kötődő, nagy távolságokra történő spóraszállítással (long-distance dispersal) állhat összefüggésben (FRAHM 2012) vagy diszjunkt areájuk a vándormadarak mozgásához, esetleg emberi tevékenységhez köthető (ZANTEN \& Pócs 1981). Ilyen fajok például a tropikus Heterophyllium affine (Hook. in Kunth) Fleisch. vagy az Észak-Amerikában elterjedt Bruchia flexuosa (Schwägr.) Müll. Hal. (FraHm 2013, 2014).

\section{Anyag és módszer}

A mohák azonosítása FREY et al. (2006), ZANDER (2007), illetve SMITH (2004) munkái alapján történt. A mohák nevezéktana PAPP et al. (2010), valamint HiLL et al. (2006), az edényes fajoké KIRÁLY (2009) munkáját követik.

\section{A Bruchia flexuosa előfordulása Magyarországon}

A Somogy-megyei savanyú, homokos talajú, nedves parlagok és belvizes szántók edényes életközösségeinek tanulmányozása során a területen előforduló mohafajok is begyüjtésre kerültek. A begyüjtött anyagból a honos és az ilyen típusú élőhelyeken többnyire gyakori moha fajok mellett rendkívül meglepő módon egy elterjedésében észak-amerikai centrummal rendelkező lombosmoha faj néhány sporofitonos példánya is előkerült. A jellegzetes, megnyúlt nyakú spóratok a növény taxonómiai hovatartozását a Bruchiaceae Schimp. családban sejttette. A mikroszkópos vizsgálatok alapján a Barcs mellett gyüjtött mohapéldányokat a hazai mohaflórára nézve új fajként, Bruchia flexuosa-ként azonosítottuk (MESTERHÁZY \& NÉMETH 2015). 
- Somogy megye; Barcs; nedves, savanyú, csupasz homoktalajon, lucernával beültetett szántó kis belvizes medencéjének peremén (1. ábra), N 45.99333ํ, E 17.52166 163 m, 2015. 05. 04. leg. Mesterházy A., 2015. 05. 18. leg. Mesterházy A. és Németh Cs., det. Németh Cs. (hb. Cs. Németh 6660, 6675). [0071.1] (2.ábra).

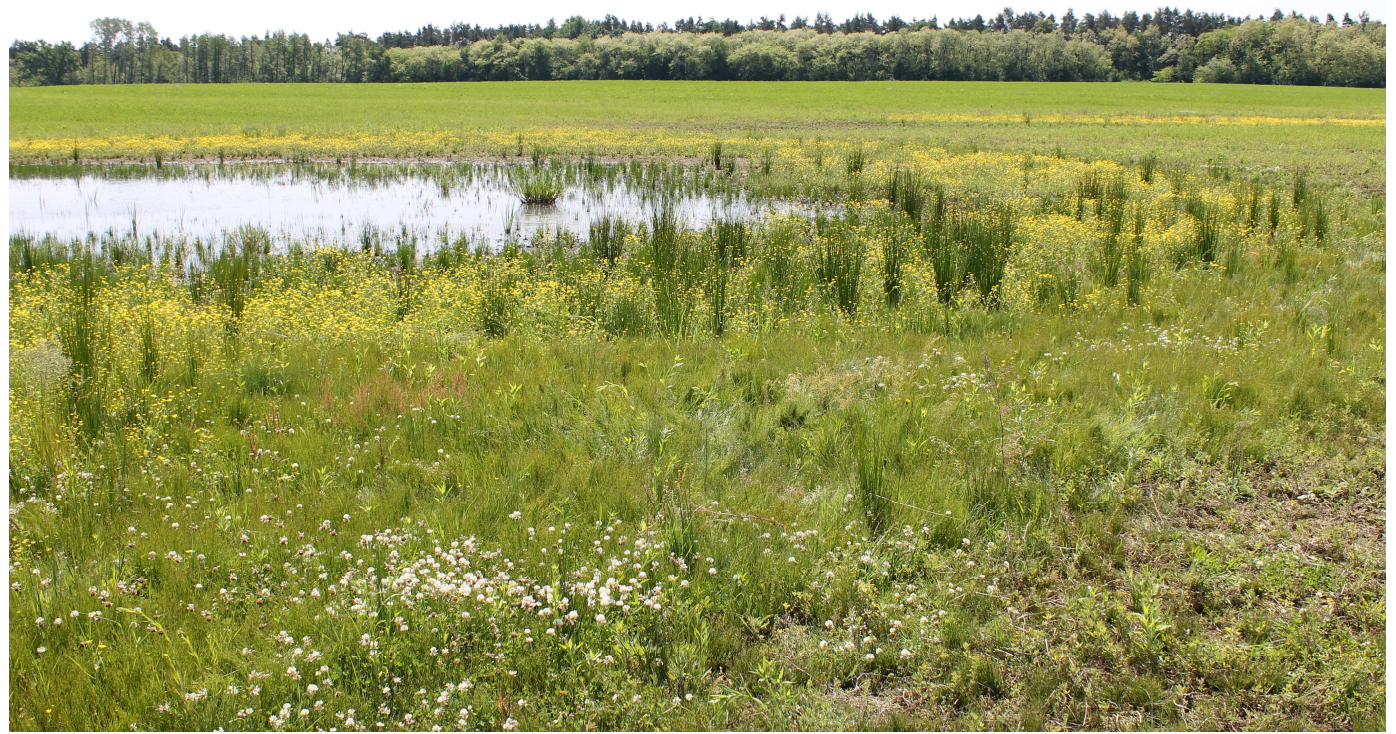

1. ábra. A Bruchia flexuosa barcsi élőhelye 2015. 05. 18-án (Németh Cs. felvétele).

Fig. 1 Habitat of Bruchia flexuosa near Barcs on 18. 05. 2015 (photo by Cs. Németh).

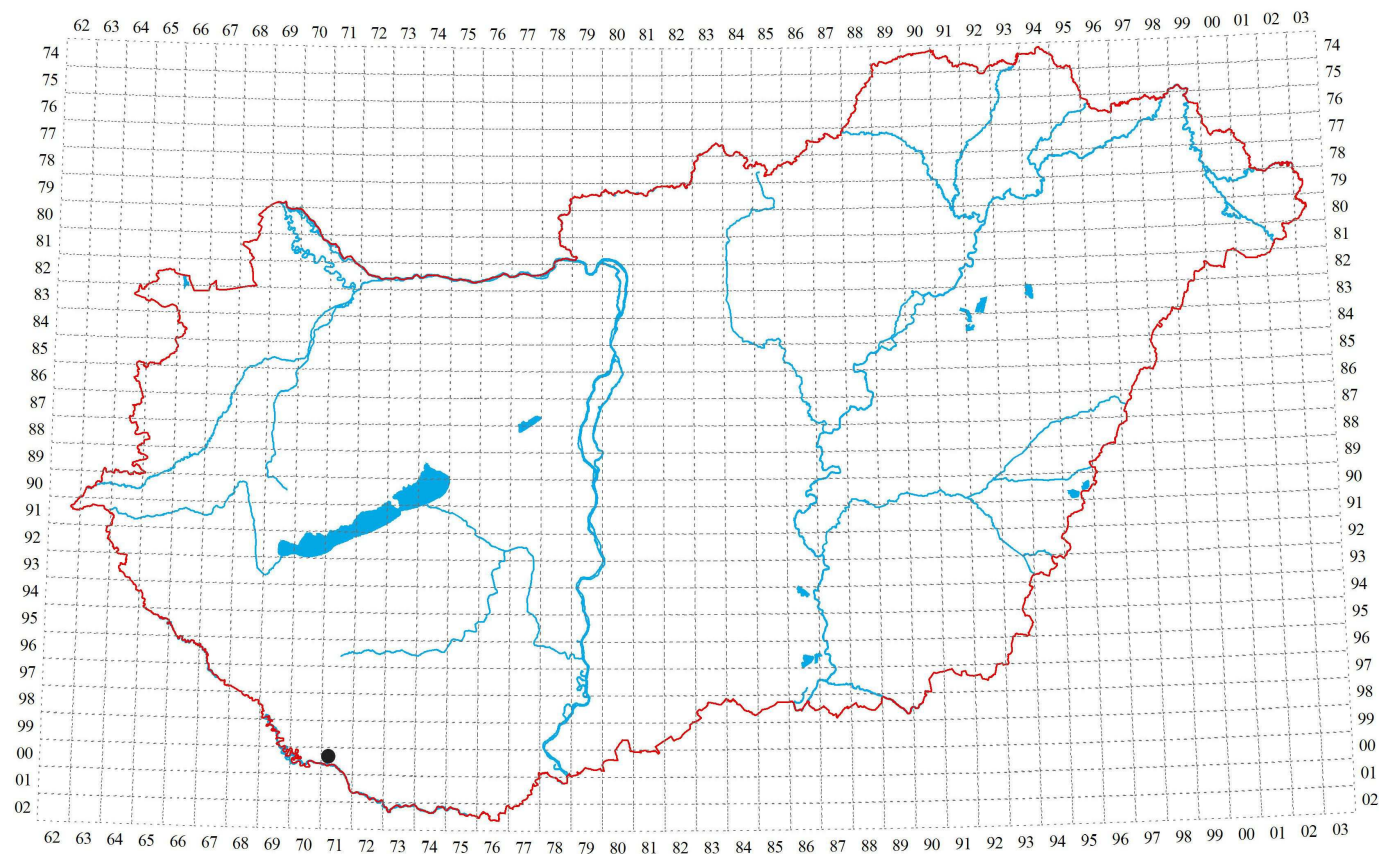

2. ábra. A Bruchia flexuosa előfordulása Magyarországon.

Fig. 2 Occurrence of Bruchia flexuosa in Hungary. 
A B. flexuosa környezetében előforduló, országosan is gyakori edényes növények a Juncus bufonius L., Ranunculus sardous Crantz, Trifolium repens L., Juncus effusus L., Lythrum hyssopifolia L., Peplis portula L., Chenopodium polyspermum L., Echinochloa crus-galli (L.) P. Beauv. és a Polygonum aviculare L., de olyan figyelemre méltó, ritka iszapnövények (Nanocyperion) is találhatók az élőhelyen, mint a Juncus tenageia Ehrh. ex L., Schoenoplectus mucronatus (L.) Palla, Eleocharis ovata (Roth) Roem. et Schult. vagy a Sagina apetala Ard.

A B. flexuosa közvetlen környezetében élő moha fajok a Funaria hygrometrica Hedw., Physcomitrium pyriforme (Hedw.) Bruch \& Schimp., Bryum argenteum Hedw., Bryum dichotomum Hedw., Ceratodon purpureus (Hedw.) Brid., Ditrichum cylindricum (Hedw.) Grout., Dicranella staphylina H. Whitehouse, Riccia bifurca Hoffm., Anthoceros agrestis Paton és Phaeoceros carolinianus (Michx.) Proskauer. A különleges élőhelyet jelzi mindkét hazánkban előforduló becősmoha (Anthocerotophyta) (Anthoceros agrestis, Phaeoceros carolinianus) együttes megjelenése is.

Az élőhely alapos átvizsgálása során mindösszesen 32 sprofitonos B. flexuosa példányt találtunk. A növény megtalálását az is nehezíti, hogy apró termete miatt gametofitonos állapotban gyakorlatilag észrevehetetlen, illetve efemer jellegénél fogva a számára kedvező, nedves élőhelyi viszonyok megváltozásával, a spóraérlelést követően nagyon hamar kiszárad és eltűnik.

A 2015-ös év tavaszán a térségben jelentős volt a belvizekkel borított területek kiterjedése, de azok döntően ősszel elművelt szántókon keletkeztek és mohaflórájuk sem volt olyan gazdag, mint azt a B. flexuosa lelőhelyén tapasztaltuk. 2015. 05. 18-án a környék számos további vízállásos szántó- és parlagterületét megvizsgáltunk, de a faj ezen élőhelyek egyikéről sem került elő.

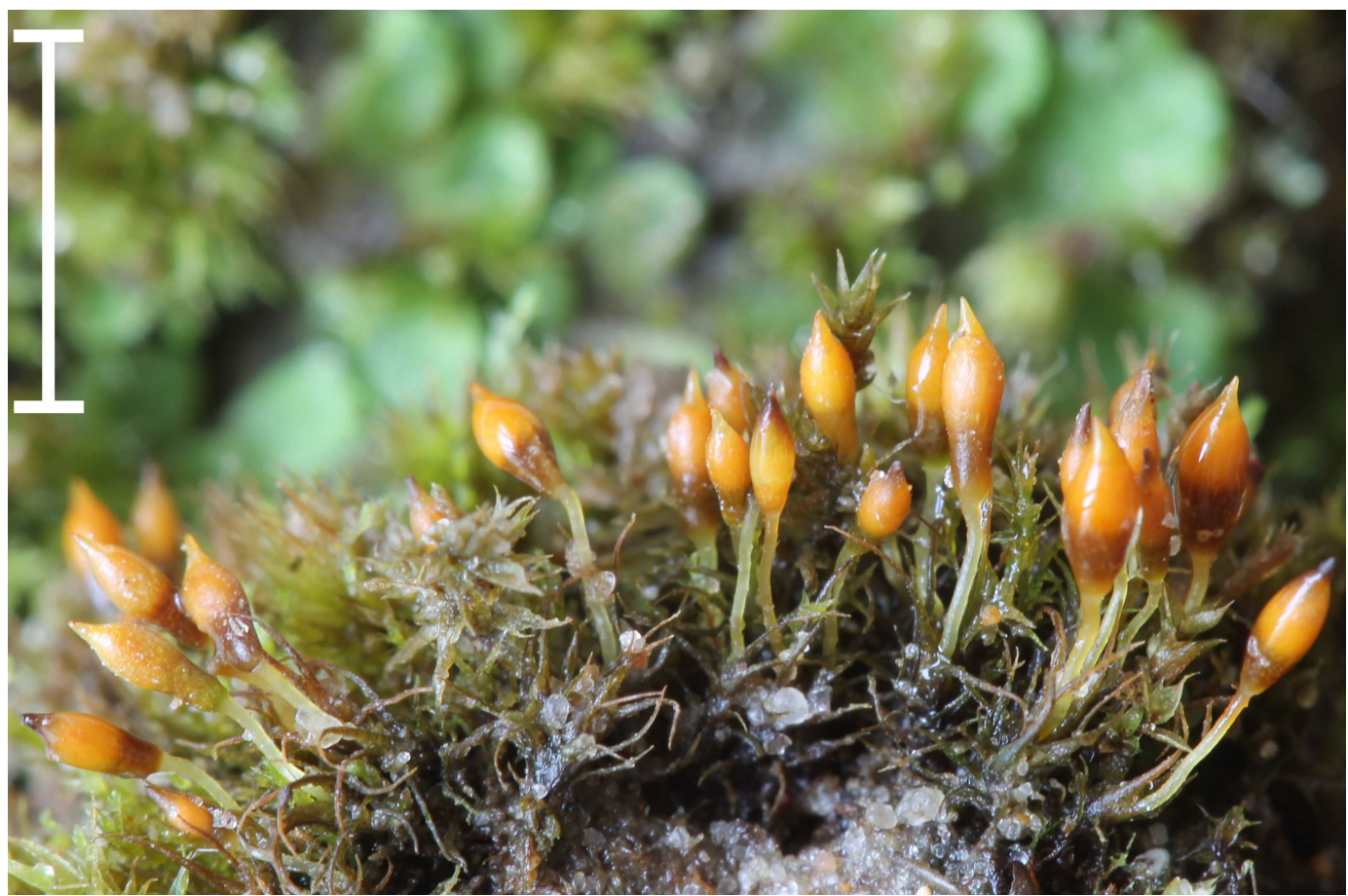

3. ábra. A Bruchia flexuosa barcsi példánya a jellegzetesen megnyúlt nyakú spóratokokkal (méretvonal: $4 \mathrm{~mm}$ ) (Németh Cs. felvétele).

Fig. 3 Specimen of Bruchia flexuosa from Barcs having capsules with distinctively elongated neck (scale bar: $4 \mathrm{~mm}$ ) (photo by Cs. Németh). 
Hogy a $B$. flexuosa ideiglenes vagy állandó tagja-e a magyar mohaflórának, arra vélhetően a következő évek felmérései fognak csak kielégítő választ adni. Mindenesetre érdekes megemlíteni, hogy a faj rendszeres monitorozására európai szinten talán most nyílik majd első alkalommal lehetőség.

\section{A Bruchia flexuosa taxonómiai és chorológiai helyzete}

A rendkívül karakterisztikus, megnyúlt nyakú spóratokkal jellemezhető Bruchiaceae család hagyományosan 4 nemzetséget foglal magába: Eobruchia W. R. Buck (2 faj), Pringleella Cardot (3 faj), Trematodon Michx. (81 faj), Bruchia Schwägr. (17 faj) (BUCK 1979, GoFFINET et al. 2009, ZANDER 2007). MAGILL (1981) emellett még a Cladophascum Sim (1 faj) nemzetséget is a családhoz sorolja. Az öt genusz közül Európában csak a sztegokarp (tokfedővel felnyíló spóratokú) Trematodon és a kleisztokarp (zárt, felhasadva nyíló spóratokú) Bruchia genusz képviselői fordulnak elő (HILL et al. 2006, HODGETTS 2015). Előbbi nemzetségnek mindössze 5 faja él Európában (egy csak Európa arktikus területein, egy az Azori-szigetek endemizmusa), míg utóbbi csak két fajjal képviselteti magát az európai kontinensen. Ezek a B. flexuosa és a B. vogesiaca Nestl. ex Schwägr. (HiLl et al. 2006).

A B. flexuosa holarktikus faj, mely Észak-Amerikában viszonylag elterjedt (ZANDER 2007). Ázsiában kizárólag Japánból jelezték két előfordulását (SchWARZ 2014), de Európában is rendkívül ritkának számít. Ez idáig mindösszesen 4 országból (Olaszország-DD (adathiányos), Ausztria-0 (kipusztult), Szlovénia-RE (kipusztult), Horvátország) került elő, mindenütt egyetlen lelőhelyről (Ros et al. 2013, HodGETTS 2015). Az olasz, osztrák és szlovén adatok a 19. századból származnak (FREY et al. 2006, FRAHM 2013), míg a horvát előfordulást Ruprecht Düll német bryológus fedezte fel 1987-ben Rab szigetén (DüLL et al. 1999). A faj jelöltként szerepel az előkészületben lévő új Európai Moha Vörös Listán is (HoDGETTS 2015).

\section{A Bruchia flexuosa rövid morfológiai jellemzése}

Kicsiny termetű, maximum 3,5 mm magas faj (3. ábra). Levelei 0,9-3,1 mm hosszúak, alsó felükben kerek-tojásdadok, középtájon hirtelen hosszú csúcsba keskenyedők, a levélér egészen a keskeny csúcsig ér, azt teljes egészében kitölti. A sejtek helyzettől függően rövid vagy hosszúkás téglalap alakúak, elkülönülő levélsaroksejtek nincsenek (4. ábra). Paroikus. Toksüvege kopasz. Hegyesen csúcsos spóratokjai rövid (0,5-3 mm) toknyélen a levelek közül kiemelkedők, körte alakúak, alapjuk felé elkeskenyedők, alsó részük egy a teljes tok hosszának 1/4-1/2 részét kitevő, számos gázcserenyílást tartalmazó nyaki részen (5. ábra) keresztül csatlakozik a toknyélhez. Tokfedő (operculum) és perisztómium nincs, a tok a spóraérést követően hasadva nyílik fel (kleisztokarp). A spórák 26-45 $\mu$ m átmérőjúek, gömb alakúak, felszínük erősen tüskés (6. ábra).

Tavaszi, nyár eleji efemer, opportunista növény, gyenge kompetíciós képességgel. Nyílt, csupasz, nedves talajfelszíneken, parlagokon, fücsomók között él. Vertikális elterjedését tekintve síkvidéki, alacsonyabb hegyvidéki karakterrel rendelkező faj.

Nemzetségének legelterjedtebb és morfológiailag legvariábilisabb tagja (RUSHING 1986). 

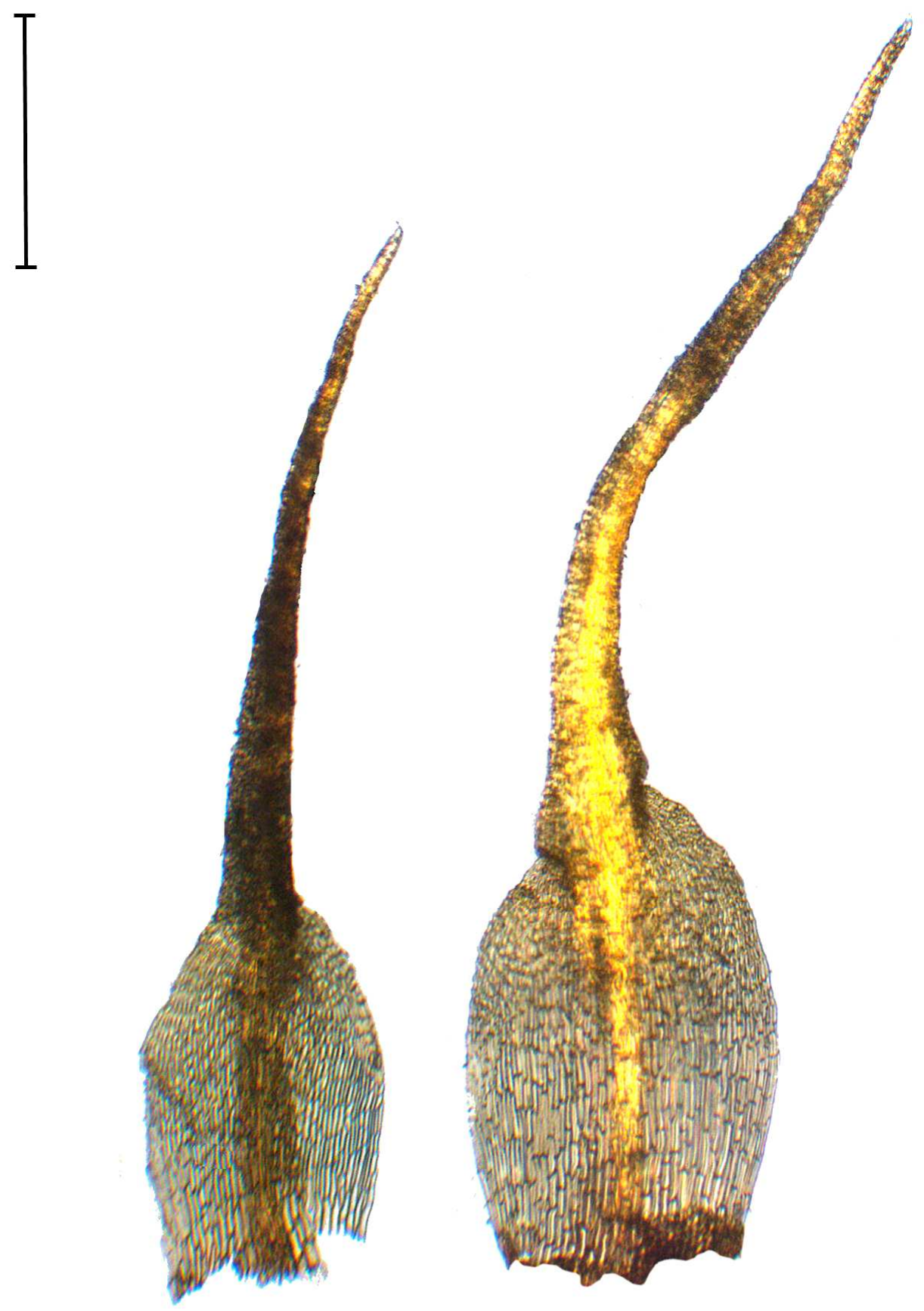

4. ábra. A Bruchia flexuosa levelei (méretvonal: $400 \mu \mathrm{m}$ ) (Németh Cs. felvétele). Fig. 4 Leaves of Bruchia flexuosa (scale bar: $400 \mu \mathrm{m}$ ) (photog by Cs. Németh). 


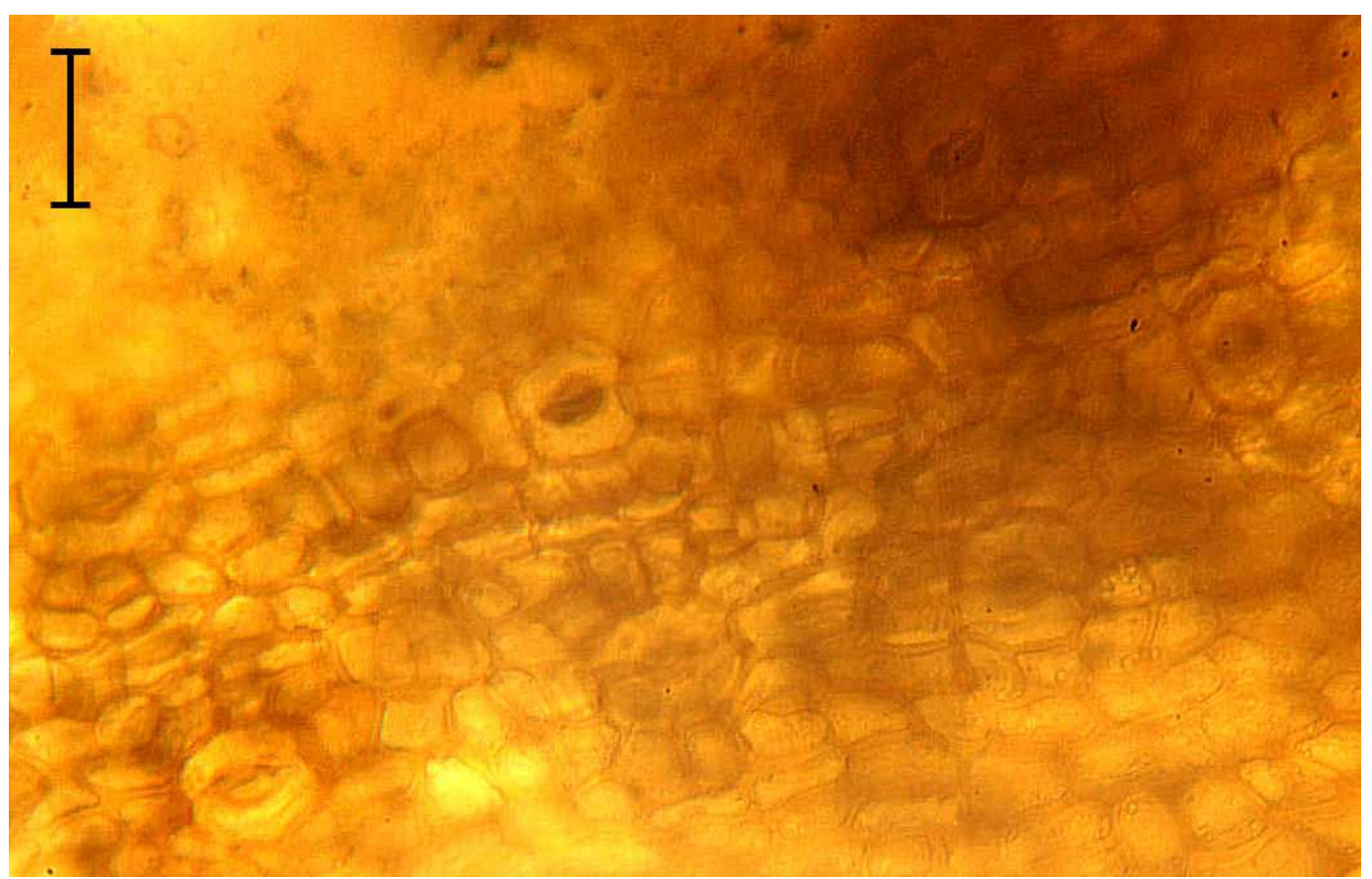

5. ábra. A Bruchia flexuosa spóratokjának nyaki része a számos gázcserenyílással (méretvonal: $40 \mu \mathrm{m}$ ) (Németh Cs. felvétele).

Fig. 5 Urn neck of Bruchia flexuosa with numerous stomata (scale bar: $40 \mu \mathrm{m}$ ) (photo by Cs. Németh).
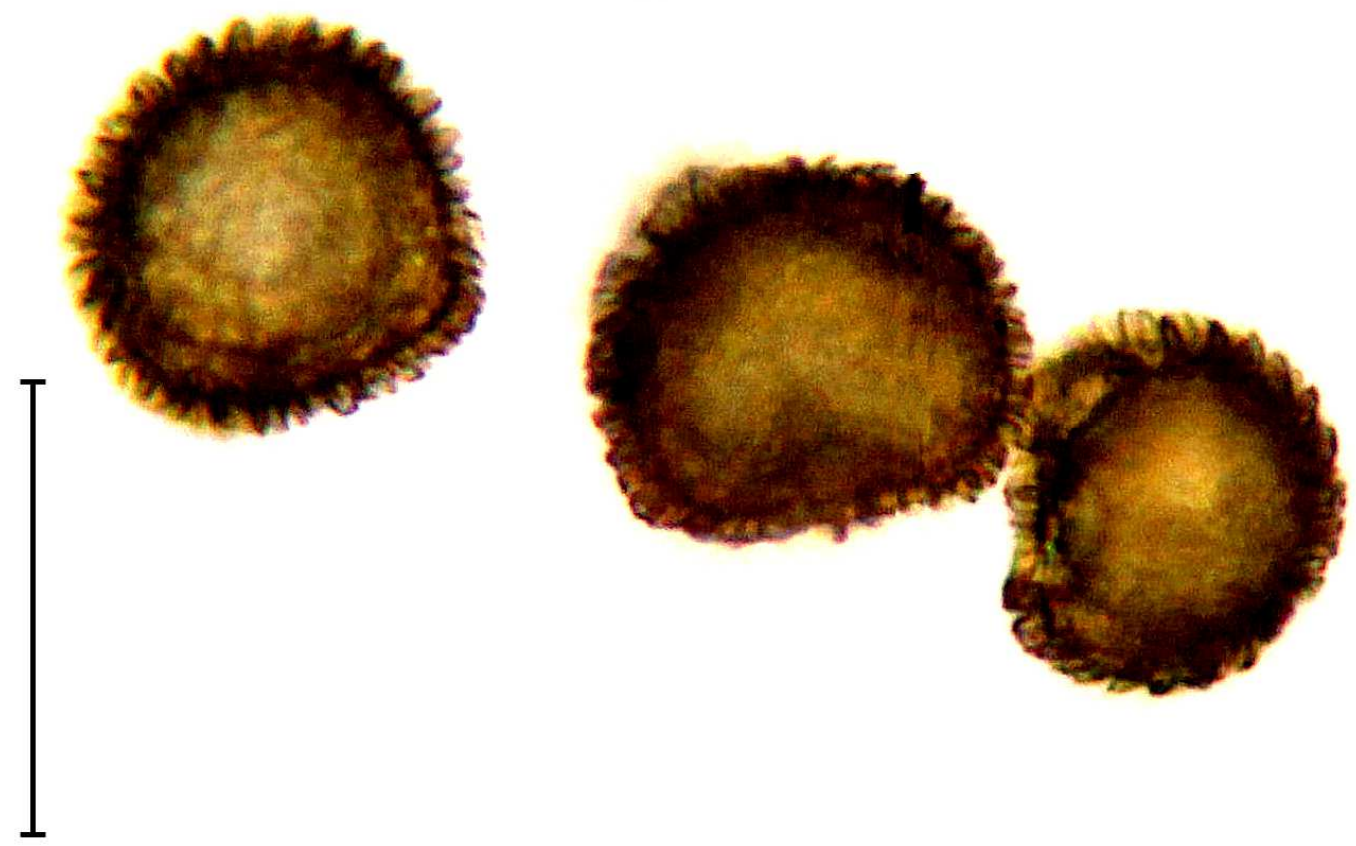

6. ábra. A Bruchia flexuosa tüskés spórái (méretvonal: $40 \mu \mathrm{m}$ ) (Németh Cs. felvétele). Fig. 6 Echinate spores of Bruchia flexuosa (scale bar: $40 \mu \mathrm{m}$ ) (photo by Cs. Németh). 


\section{Köszönetnyilvánítás}

Köszönettel tartozunk Peter Erzbergernek a kézirathoz füzött építő észrevételeiért, valamint néhány kísérő mohafaj meghatározásáért, Pócs Tamásnak a kézirat lektorálásáért, Antun Alegronak pedig a faj horvátországi előfordulásával kapcsolatos információkért.

\section{Irodalom}

Boros Á. (1915-1971): Florisztikai jegyzetek. - MTM, Tudománytörténeti Gyűjtemény, Budapest, mscr. Boros Á. (1968): Bryogeographie und Bryoflora Ungarns. - Akadémiai Kiadó, Budapest, 466 pp.

Buck W. R. (1979): A re-evaluation of the Bruchiaceae with the description of a new genus. - Brittonia 31: 469-473.

BURREL W. H. (1940): A field study of Orthodontium gracile (Wilson) Schwaegrichen and its variety heterocarpum Watson. - Naturalist 785: 295-302.

Csiky J., Erzberger P., KovÁcs D. \& Deme J. (2015): Campylopus flexuosus (Hedw.) Brid. a NyugatMecsekben. - Kitaibelia 20: 28-37.

Düll R., Ganeva A., MartinčIč A. \& Pavletić Z. (1999): Contributions to the bryoflora of former Yugoslavia and Bulgaria. - Bryologische Beiträge 11: 1-99.

ERZBERGER P. \& SchröDER W. (2008): The genus Schistidium (Grimmiaceae, Musci) in Hungary. - Studia botanica hungarica 39: 27-88.

Erzberger P. \& Németh Cs. (2014): Campylopus flexuosus (Hedw.) Brid. [Hungary]. - In: Ellis T. L. (ed.), New national and regional bryophyte records, 39. - Journal of Bryology 36: 134-151.

FRAHM J.-P. (2012): The phytogeography of European bryophytes. - Botanica Serbica 36: 23-36.

FRAHM J.-P. (2013): Nordamerikanische Moosarten in Europa. - Archive for Bryology 160, 10 pp.

FRAHM J.-P. (2014): Tropische Moosarten in Europa. - Archive for Bryology 197, 8 pp.

Frey W., Frahm J-P., Fischer E. \& LoBin W. (2006): The liverworts, mosses and ferns of Europe. Translated, revised and edited by T.L. Blockeel. Harley Books, 512 pp.

Goffinet B., Buck W. R. \& ShaW A. J. (2009): Morphology, anatomy, and classification of the Bryophyta. In: Goffinet B. \& ShaW A. J. (eds), Bryophyte Biology (second edition). Cambridge University Press, Cambridge, pp. 53-138.

HASSEL K. \& SöDERSTRÖM L. (2005): The expansion of the alien mosses Orthodontium lineare and Campylopus introflexus in Britain and continental Europe. - Journal of the Hattori Botanical Laboratory 97: 183-193.

Hill M. O., Bell N., Bruggeman-Nannenga M. A., Brugués M., Cano M. J., Enroth J., Flatberg K. I., Frahm J.-P., Gallego M. T., Garilleti R., Guerra J., Hedenäs L., Holyoak D. T., Hyvönen J., Ignatov M. S., Lara F., MAZIMPAKA V., MunOZ J. \& SÖDERSTRÖM L. (2006): An annotated checklist of the mosses of Europe and Macaronesia. - Journal of Bryology 28: 198-267.

HodGETTS N. G. (2015): Checklist and country status of European bryophytes - towards a new Red List for Europe. - Irish Wildlife Manuals, No. 84. National Parks and Wildlife Service, Department of Arts, Heritage and the Gaeltacht, Ireland.

JAKAB G. (1997): A piricsei Júlia-liget botanikai értékei II. (Mohák - Bryophyte). - Kitaibelia 2: 46-50.

KIRÁLY G. (szerk.) (2009): Új magyar füvészkönyv. Magyarország hajtásos növényei. Határozókulcsok. ANPI, Jósvafő, 616 pp.

MAGill R. E. (1981): Bryophyta, Part I. Mosses. Fasc. I. Sphagnaceae - Grimmiaceae. - In: LeISTNER O. A. (ed.), Flora of Southern Africa. Republic of South Africa.

Mesterházy A. \& NÉmETH Cs. (2015): Bruchia flexuosa (Schwaegr.) Müll.Hal. [Hungary]. - In: Ellis L. T. (ed.), New national and regional bryophyte records. - Journal of Bryology 37: (in press)

MikulášKová E., Fajmonová Zs. \& HÁjEK M. (2012): Invasion of central-European habitats by the moss Campylopus introflexus. - Preslia 84: 863-886.

NÉmETH Cs. (2008): Adatok a Súri-Bakonyalja, a Bakony és a Vértes mohaflórájához. - Flora Pannonica 6: 79-87.

PAPP B. (2009a): Gymnostomum viridulum Brid. [Hungary]. - In: BLockeEL T. L. (ed.), New national and regional bryophyte records, 21. - Journal of Bryology 31: 132-139. 
PAPP B. (2009b): The bryophyte flora of the Aggtelek National Park. - In: PAPP B. (ed.), The flora of the Aggtelek National Park. Cryptogams. Natural history of the national parks of Hungary. Magyar Természettudományi Múzeum, Budapest, vol. 14, pp. 175-230.

Papp B., ERZberger P., Ódor P., Hock Zs., SzövÉnyi P., SzuRdoki E. \& Tóth Z. (2010): Updated checklist and red list of Hungarian bryophytes. - Studia botanica hungarica 41: 31-59.

RajCZY M. (1990): Mohák - Bryophyta. - In: RaKonczAI Z. (szerk.), Vörös Könyv. Akadémiai Kiadó, Budapest, pp. 322-325.

Richards P. W. (1963): Campylopus introflexus (Hedw.) Brid. and C. polytrichoides De Not. In the British isles; a preliminary account. - Transactions of the British Bryological Society 4: 404-417.

Ros R. M., Mazimpaka V., Abou-Salama U., Aleffi M., Blockeel T. L., Brugues M., Cros R. M., Dia M. G., Dirkse G. M., Draper I., El-SaAdawi W., Erdag A., Ganeva A., Gabriel R., Gonzalez-Mancebo J. M., Granger C., Herrnstadt I., Hugonnot V., Khalil K., Kurschner H., Losada-Lima A., Luis L., Mifsud S., Privitera M., Puglisi M., Sabovljević M., Sergio C., Shabbara H. M., Sim-Sim M., SotiauX A., Tacchi R., Vanderpoorten A. \& WERNER O. (2013): Mosses of the Mediterranean, an annotated checklist. - Cryptogamie, Bryologie 34: 99-283.

Rushing A. E. (1986): A revision of the genus Bruchia Schwaegr. (Musci). - Journal of the Hattori Botanical Laboratory 60: 35-83.

Schwarz U. (2014): Contribution to the Bryophyte Flora of Shinagawa, Tokyo, Japan. - Frahmia 2: 1-29.

Sмiтн A. J. E. (2004): The mossflora of Britain and Ireland. - Cambridge University Press, Cambridge, $1012 \mathrm{pp}$.

SzŰCS P. (2007): A Campylopus introflexus (Hedw.) Brid. új hazai előfordulása az Ácsi-erdőben. Kitaibelia 12: 145.

Szúcs P. (2009): A Campylopus introflexus (Hedw.) Brid. új hazai adata a Bockerek-erdőből. - Kitaibelia 14: 123.

SzúcS P. (2012): A neofiton Campylopus introflexus (Hedw.) Brid. újabb hazai előfordulása Tatabányánál. - Kitaibelia 18: 186.

Szúcs P. \& BidLó A. (2012): Orthodontium lineare Schwägr. [Hungary]. - In: Ellis L. T. (ed.), New national and regional bryophyte records, 33. - Journal of Bryology 34: 284-285.

SzÚcs P. \& ERzBerger P. (2007): Campylopus introflexus (Hedw.) Brid. [Hungary]. - In: Blockeel T. L. (ed.) New national and regional bryophyte records, 16. - Journal of Bryology 29: 199.

SzÛ́cs P., CSIKY J. \& PAPP B. (2014): A neofiton Campylopus introflexus (Hedw.) Brid. elterjedése Magyarországon. - Kitaibelia 19: 212-219.

YAyınTAŞ Ö. T. (2009): Campylopus introflexus (Hedw.) Brid. [Turkey]. - In: BlockeEL T. L. (ed.), New national and regional bryophyte records, 20. - Journal of Bryology 31: 55.

Vellak K., IngerpuU N., KANNUKENE L. \& LeIS M. (2009): New Estonian records and amendments: Liverworts and mosses. - Folia Cryptogamica Estonica 45: 91-93.

ZANDER R. H. (2007): Bruchiaceae. - In: Flora of North America North of Mexico. Volume 27. Bryophyta, part 1. New York: Oxford University Press. http://www.mobot.org/plantscience/bfna/V1/Bruchiaceae.htm

ZANTEN B. O. VAN \& Pócs T. (1981): Distribution and dispersal of bryophytes. - Advances in Bryology 1: 479-562.

ZANTEN B. O. VAN (2000): Studies on the cryptogamic vegetation of loess cliffs, IV. Chenia leptophylla (C. Müll.) Zander, new to Hungary. - Kitaibelia 5: 271-274.

Beérkezett / received: 2015. 08. 19. Elfogadva / accepted: 2015. 09. 15. 